\title{
Creativepreneur: Optimalisasi produk animasi "simbah" dalam komersialisasi kekayaan intelektual
}

\section{Creativepreneur: Optimization of animation products "siMbah" in the commercialization of intellectual property}

\author{
Dhanar Intan Surya Saputra ${ }^{a}$, Asih Udianti ${ }^{b}$, Rahman Rosyidi c, Berlilana Berlilana ${ }^{d}$ \\ a Informatika, Universitas Amikom Purwokerto, Purwokerto, Indonesia \\ b,c,d Sistem Informasi, Universitas Amikom Purwokerto, Purwokerto, Indonesia \\ email:adhanarsaputra@amikompurwokerto.ac.id, basihudianti967@gmail.com, camang@amikompurwokerto.ac.id, \\ d berli@amikompurwokerto.ac.id
}

\begin{tabular}{l}
\hline I N F O A R T I K E L \\
\hline Sejarah artikel: \\
Menerima 17 Juni 2020 \\
Revisi 21 Juli 2020 \\
Diterima 3 Agustus 2020 \\
Online 6 Agustus 2020 \\
\hline
\end{tabular}

Kata kunci: analisis bauran pemasaran animasi creativepreneur ekonomi kreatif merchandise

Keywords: animation creative economy creativepreneur marketing mix merchandise

\begin{abstract}
ABSTRAK
Creativepreneur merupakan entrepreneur dengan jiwa kreatif, selalu melahirkan dan menciptakan inovasi, gagasan, dan berpikir secara "out of the box". Ampu Kreatif Studio (Ampu Studio) merupakan salah satu studio animasi sebagai unit bisnis di Universitas Amikom Purwokerto yang memiliki produk kreatif berupa Serial Animasi 3D siMbah (siMbah). Animasi ini mengenalkan budaya dan adat Jawa Tengah. Tantangan industri yang dihadapi Ampu Studio yaitu pemasaran produk dan jasa animasi yang belum maksimal, belum banyak masyarakat yang telah mengenal siMbah saat ini, serta adanya peluang value produk kreatif berupa merchandise dari hasil komersialisasi siMbah. Data penelitian diperoleh melalui metode yaitu observasi, kuesioner, wawancara, dan dokumentasi serta studi pustaka. Dalam penelitian juga dilakukan identifikasi digital marketing dari hasil komersialisasi kekayaan intelektual dan analisis bauran pemasaran. Analisis bauran pemasaran menunjukkan produk yang tepat untuk dipasarkan, penentuan harga yang tepat, saluran distribusi yang akan digunakan untuk memasarkan produk, dan promosi untuk mengenalkan produk. Analisis bauran pemasaran yang ditetapkan dalam penelitian ini adalah untuk analisis value produk berupa merchandise dari hasil komersialisasi. Kategori produk merchandise untuk siMbah yaitu produk hardlines, produk softlines, produk homeliness dan produk groceries. Pembuatan akun media sosial siMbah dilakukan dengan tujuan untuk mengenalkan siMbah kepada masyarakat luas. Dari analisis yang telah dilakukan pada Ampu Studio untuk siMbah didapatkan hasil berupa perencanaan strategi untuk produk kreatif berupa produk-produk merchandise. Hasil strategi digital marketing yaitu melalui sosial media berupa Facebook, Instagram, YouTube, marketplace, dan web toko online untuk pemasaran produk. Penelitian ini dapat dikembangkan oleh peneliti berikutnya dengan membuat web e-commerce untuk produk-produk kreatif merchandise siMbah. Hasil penelitian ini diharapkan dijadikan sebagai bahan pertimbangan Ampu Studio dalam pengambilan adanya keputusan untuk mencapai tujuan bisnis dengan memproduksi produk kreatif berupa merchandise siMbah yang akan menjadi peluang bisnis yang akan datang.
\end{abstract}

ABSTRACT 
Style APA dalam menyitasi artikel ini:

Saputra, D. I. S., Udianti, A., Rosyidi, R., \& Berlilana, B. (2020). Creativepreneur: Optimalisasi produk animasi "simbah" dalam komersialisasi kekayaan intelektual. Teknologi: Jurnal Ilmiah Sistem Informasi, 10(1), $32-42$.
Creativepreneur is an entrepreneur with a creative mind, always engender and create innovation, ideas and thinking "out of the box". Creativepreneur is an entrepreneur with a creative mind, always engender and create innovation, ideas and thinking "out of the box". Ampu Creative Studio (Ampu Studio) is one of the animation studios as a business unit in the University of Amikom Purwokerto which has a creative product in the form of 3D Animation Series (siMbah) to introduce Central Javanese culture and customs. The industrial challenges by Ampu Studio are the marketing of products and animation services that has not been maximized, Not many people are familiar with siMbah at this time, and there are opportunities for the value of creative products in the form of merchandise from the commercialization of siMbah. The research data obtained through the methods of data collection are observation, questionnaires, interviews, documentation and literature. The research also identified digital marketing from the results of the commercialization of intellectual In studies also do marketing digital identification from the commercialization of intellectual property and marketing mix analysis. Marketing mix analysis showed the right product for the market, determining the right price, distribution channels that will be used to market the product, and promotion to introduce the product. Analysis of the marketing mix are defined in this study is to analyze the value of the product in the form of merchandise from the commercialization. The product categories for siMbah are hard lines, soft lines, homeliness products and groceries. The creation of a siMbah social media account is carried out with the aim of introducing siMbah to the wider community. the analysis has been done on Ampu Studio for siMbah is obtained in the shape of strategic planning for the creative product in the shape of merchandise products. The results of digital marketing strategy through social media such as Facebook, Instagram, YouTube, marketplace, and online web store for marketing the product. This research can be developed by subsequent researchers to create an e-commerce web for creative products siMbah merchandise. The results of this study can be used as Ampu Studio's consideration in making a decision to achieve business goals by producing creative products in the form of the siMbah merchandise which will become a business opportunity going forward.

Teknologi: Jurnal IImiah Sistem Informasi dengan lisensi CC BY NC SA.

\section{Pendahuluan}

PT. Ampu Kreatif Studio (Ampu Studio) merupakan salah satu studio animasi sebagai unit bisnis di Universitas Amikom Purwokerto, Jawa Tengah. Ampu Studio memiliki potensi untuk mengembangkan produk ekonomi kreatif di Indonesia melalui konten animasi. Sebagai unit bisnis di perguruan tinggi, perkembangan Ampu Studio diharapkan dapat memiliki dampak positif bagi mahasiswa dalam perkembangan industri animasi di Indonesia sehingga meningkatkan nilai ekonomi kreatif.

Ampu Studio berdiri pada tahun 2014 diawali sebagai Komunitas Animasi di STMIK Amikom Purwokerto. Hal tersebut berbanding lurus dengan alih status STMIK Amikom Purwokerto berubah menjadi Universitas Amikom Purwokerto, serta seiring kepercayaan masyarakat dan produktivitas karya, maka resmi berganti nama menjadi PT. Ampu Kreatif Studio di tahun 2016. Hal ini tentu berdampak terhadap meningkatnya produk-produk inovasi dalam bidang teknologi dan informasi baik ditingkat lokal atau daerah, nasional maupun internasional.

Ampu Studio telah memiliki banyak karya, baik layanan jasa maupun produk kekayaan intelektual, salah satunya serial animasi 3D siMbah (siMbah). siMbah merupakan film pendek serial yang tayang di YouTube channel, bercerita tentang sosok seorang kakek dengan kesehariannya. siMbah juga menjadi media untuk mengenalkan budaya dan adat daerah khususnya Jawa Tengah. siMbah dikemas dengan animasi tiga dimensi (3D) bergenre komedi slapstick, yaitu hiburan dalam bentuk komedi secara fisik agar mudah dicerna oleh penonton melalui adanya kelucuan gerak adegan oleh para pemainnya (Hessler, 2019). Karakter siMbah diangkat dari sebuah budaya masyarakat Jawa Tengah yang menggunakan pakaian adat Jawa lengkap beskap dengan blangkon. Penggambaran karakter animasi 3D siMbah terlihat pada Gambar 1, sebagai bentuk cover film.

Industri animasi adalah salah satu jenis industri kreatif di masa depan yang akan membuka banyak kesempatan kerja bagi generasi muda. Perkembangan industri animasi sudah dimulai sejak tahun 1900-an, di Indonesia sendiri animasi semakin meningkat dengan adanya penetrasi dari saluran 
media digital seperti televisi, internet dan sosial media.

Animasi merupakan cara dalam menggerakkan gambar dengan mengumpulkan dan menata gambar secara urut dalam sebuah layer sehingga ketika gambar itu dijalankan terkesan hidup (Handani \& Nafianti, 2017). Sedangkan (Munir, 2013) menyatakan bahwa animasi sebagai bentuk perubahan visual sepanjang waktu yang memiliki kekuatan besar pada proyek multimedia dalam halaman web yang dimuat, banyak aplikasi multimedia yang menyediakan fasilitas animasi. Asal kata animasi yaitu "anima" dari Bahasa Latin yang memiliki arti "hidup, jiwa dan semangat". Animasi dalam Bahasa Inggris "animation" dengan kata dasar to anime, yang dapat diartikan "menghidupkan". Definisi animasi merupakan kegiatan mengolah gambar yang dilakukan untuk menghidupkan dan menggerakkan melalui proses secara digital dengan cara adanya unsur kekuatan, dorongan, semangat dan emosi sehingga benar-benar terasa hidup. Animasi juga dapat diartikan sebagai gambar yang terdiri atas objek atau banyaknya gambar sehingga melalui penglihatan mata manusia berasa hidup, disebabkan banyaknya kumpulan gambar yang berubah secara teratur dan bergantian untuk ditampilkan. Objek gambar tersebut berupa tulisan, bentuk benda, shape, karakter, warna dan/atau spesial efek. Pelaku dalam bidang animasi salah satunya disebut sebagai animator (Handani, Suyanto, \& Sofyan, 2016).

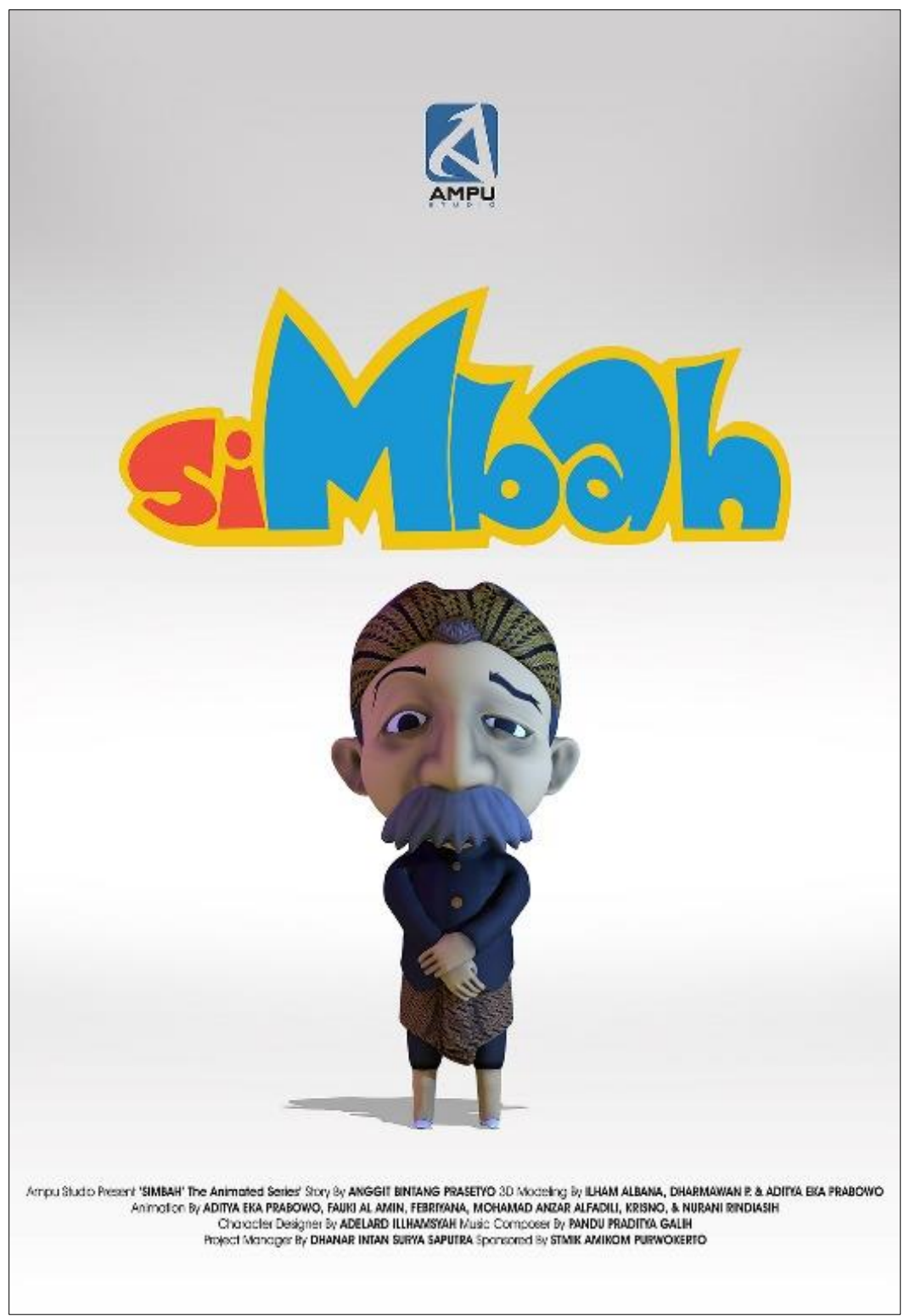

Gambar 1. Poster film Serial Animasi 3D siMbah

Animasi masuk sebagai subsektor ekonomi kreatif yang saat ini sedang mengalami perkembangan positif, hal ini tak lepas dari jumlah potensi penonton di Indonesia yang sangat banyak dan bisa mengapresiasi film atau karya produksi lokal secara positif. Sebagai lembaga pemerintah, 
Kementerian Pariwisata dan Ekonomi Kreatif Republik Indonesia (Kemenparekraf) mengkategorikan menjadi 16 (enam belas) subsektor ekonomi kreatif, yaitu aplikasi dan pengembang permainan, arsitektur, desain interior, desain komunikasi visual, fashion, desain produk, film, animasi dan video, kriya, fotografi, kuliner, musik, periklanan, penerbitan, seni pertunjukan, seni rupa, televisi dan radio. Sektor ekonomi kreatif di Indonesia terbukti banyak mewujudkan wirausahawan baru, baik di tingkat mahasiswa maupun umum (Saputra, Indartono, Handani, \& Hermawan, 2020), tingkat daya saing inovasi ekonomi kreatif juga menunjukkan adanya peningkatan grafik yang tinggi (Saputra, Indartono, \& Handani, 2019).

Indonesia merupakan salah satu negara dengan kinerja ekonomi yang hebat, memiliki Pertumbuhan Domestik Bruto (PDB) sebesar 5,02\% di tahun 2019 (BPS, 2020). Adanya potensi dari industri animasi menjadikan Indonesia untuk terus meningkatkn kembali animasi sebagai salah satu bagian dari kekuatan ekonomi kreatif (Rahmadianto, Prasetia, \& Andito, 2019). Animasi sebagai salah satu dari enam belas subsektor industri kreatif, tentu memiliki potensi distribusi tidak hanya di dalam negeri tetapi juga pasar global. Seperti halnya game, animasi tersebut diproduksi tidak hanya untuk bisnis saja, namun untuk kebutuhan lain seperti Pendidikan (Bachtiar \& Hakim, 2016).

Pasar animasi di Indonesia pada umumnya, didominasi oleh perusahan besar dari luar negeri seperti Walt Disney, Pixar Animation Studio, DreamWorks Animation, Universal Studio, Warner Bros dan beberapa studio besar lainnya. Selain itu, hadir beberapa industri animasi dari studio besar dalam negeri yang bernaung di bawah stasiun televisi, seperti MNC Animation, MD Animation, Trans7, Emtek Group dan Dreamtoon serta production house atau studio lainnya (Ilyas, Raharja, \& Muhandri, 2016). Indonesia juga memiliki banyak animasi buatan lokal karya anak bangsa seperti Battle of Surabaya, Super Neli, Meraih Mimpi, KIKO, dan Petualangan si Adi serta beberapa animasi lainya (Sofiandy \& Mustikasari, 2018).

Menurut McCarthy (Sefudin, 2014), aktivitas bauran pemasaran dapat dikelompokkan menjadi 4P yaitu product, price, place dan promotion. Produk (Product) berupa objek yang ditawarkan dan tersedia di pasar untuk dapat memenuhi segala kebutuhan dan keinginan para konsumen. Produk tidak hanya meliputi objek fisik tetapi juga dapat berupa jasa, orang, tempat, acara, ide, organisasi, dan/atau kombinasi, termasuk keragaman produk, desain, ciri, kualitas, merek, kemasan, ukuran, garansi, imbalan dan pelayanan. Harga (Price) yaitu pengukuran nilai dari objek produk, nilai tersebut dapat diukur dalam bentuk uang atau alat transaksi lainnya, termasuk di dalamnya daftar harga, diskon atau potongan harga, syarat kredit dan periode pembayaran. Distribusi (Place) yaitu kegiatan yang saling tergantung dan terlibat dalam proses produk atau jasa siap digunakan oleh konsumen atau dikonsumsi, termasuk di dalamnya cakupan pasar, saluran pemasaran, pengelompokan lokasi, persediaan transportasi. Promosi (Promotion) berupa komunikasi yang memberi penjelasan dalam meyakinkan kepada calon konsumen tentang produk tersebut dengan maksud untuk mendapatkan perhatian, mendidik, meyakinkan dan mengingatkan. Termasuk di dalamnya promosi penjualan, tenaga penjualan, public relation, periklanan, dan pemasaran langsung.

Industri animasi sebagai salah satu bentuk dan upaya dari pengembangan dan inovasi entrepreneur kemudian memunculkan istilah baru berupa creativepreneur. Creativepreneur yaitu seseorang atau individu yang memulai atau menjual bisnisnya dengan menggunakan ide kreatif, hal ini biasanya tidak jauh dari bidang seni atau desain sebagai tolak ukur utamanya. Creativepreneur dan entrepreneur merupakan bidang yang memiliki sedikit kesamaan. Persamaannya terletak yaitu pada kesamaan dalam hal menjual dan menawarkan produk, menjalani sebuah proses, hingga memanfaatkan teknologi digital. Entrepreneur memperhatikan perihal permodalan, mengenali produk, dan strategi untuk pertumbuhan yang cepat pada bidang usahanya termasuk pada pangsa pasar dari produk tersebut. Creativepreneur merupakan wujud wirausaha di bidang kreatif dan mengembangkan inisiatif untuk mendapatkan pasar industri dan ekonomi kreatif (Silitonga, 2018). Creativepreneur sebagai entrepreneur yang berjiwa kreatif akan selalu melahirkan dan menciptakan inovasi terbaru, gagasan, dan dapat berpikir secara "out of the box". Bidang yang berkaitan dengan creativepreneur cukup banyak, diantaranya bidang animasi, grafis, desain komunikasi visual, arsitektur, interior, seni dan tari, pengembang game, musik, kerajinan, foto dan videografi serta masih banyak lagi.

Ada beberapa permasalahan yang terjadi dalam industri animasi diantaranya pemasaran produk dan jasa animasi yang belum maksimal, belum memiliki brand awarness yang kuat, belum memiliki 
wawasan tentang ilmu branding dan identitas untuk menunjang pemasaran produk. Pengaruh ada atau tidaknya memiliki dokumen standar sistem identitas atau corporate identity system sebagai panduan penting penerapan identitas untuk berbagai kebutuhan dalam produksi animasi (Rahmadianto, Prasetya, \& Andito, 2019). Hal ini tentunya menjadi permasalahan sendiri yang perlu penanganan, sehingga dapat menjaga konsistensi identitas perusahaan, dalam hal ini studio.

Adanya segmenting, targeting dan positioning dari film animasi juga dapat mengukur sejauh mana masyarakat dapat menyukai film animasi (Sofiandy \& Mustikasari, 2018), sehingga strategi pemasaran produk animasi dari setiap studio tentunya akan berbeda dengan studio lainnya, selain itu mitra-mitra pemasaran antar studio juga cukup berpengaruh (Ilyas, Raharja, \& Muhandri, 2016). Beberapa studio besar di luar negeri bahkan sudah dapat menghasilkan profit dari adanya inovasi produk dari turunan animasi, baik merchandise maupun produk digital lainnya (Jiao, Wang, Xiao, Zhou, \& Zeng, 2017). Tentunya segmenting, targeting dan positioning animasi tidak hanya pada anak-anak, tetapi juga dapat melebar usia dewasa atau bahkan segala usia (Vijayakrishnan, Harikrishnan, Babu, \& Kochi, 2018).

Berdasarkan uraian tersebut, maka pada penelitian ini diusulkan optimasi pengembangan produk animasi "siMbah" dalam komersialisasi Kekayaan Intelektual (KI) di Ampu Studio yang menjadi salah satu bagian dari creativepreneur. KI adalah hak eksklusif yang diberikan suatu hukum atau peraturan kepada seseorang individu, sekelompok orang atau lembaga atas karya ciptanya. Dengan adanya pencatatan KI maka pemilik produk tersebut dapat menikmati secara ekonomi hasil dari suatu KI, melalui jual beli secara legal dan atau royalty yang muncul dari produk tersebut. Objek yang diatur dalam KI yaitu karya-karya yang timbul atau lahir karena kemampuan intelektual manusia (Praja, 2017). Hasil dari penelitian ini diharapkan dapat menyajikan informasi berupa peluang pengembangan produk atau layanan jasa dari hasil KI yang dihasilkan oleh PT. Ampu Kreatif Studio.

\section{Material dan Metode}

Penelitian ini membutuhkan adanya data-data pendukung yang dapat diperoleh melalui metode pengumpulan data yang relevan, yaitu observasi, pengamatan yang dilakukan adalah untuk mengetahui apakah masyarakat sudah mengenal Serial Animasi 3D siMbah (siMbah) saat ini, dilanjutkan dengan kuesioner, guna mengetahui adanya faktor-faktor internal dan eksternal yang berkaiatan dengan value produk kreatif berupa merchandise dari hasil komersialisasi siMbah. Tahap berikutnya yaitu wawancara, studi pustaka dan dokumentasi.

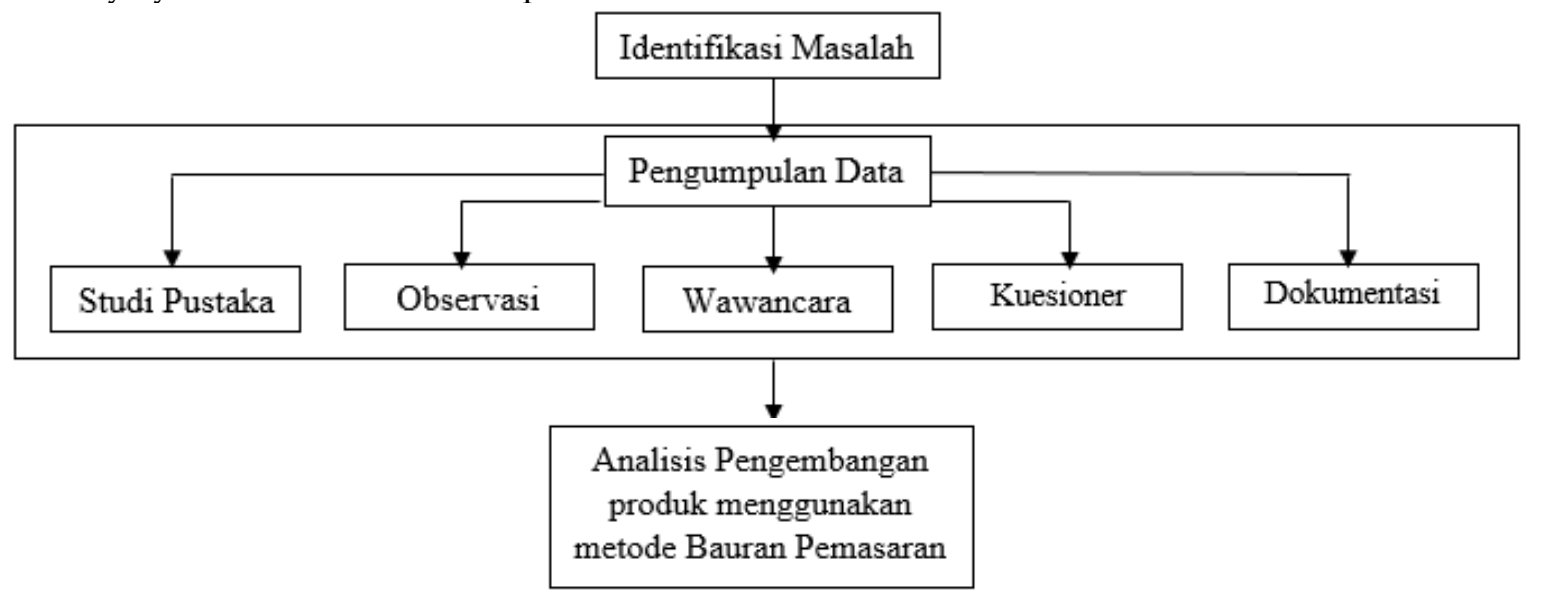

Gambar 2. Kerangka berfikir penelitian

Pada serangkaian kegiatan penelitian ini juga dilakukan proses identifikasi digital marketing pada siMbah, sehingga dapat dilakukan pengembangan produk dari hasil komersialisasi kekayaan Intelektual (KI). Tahap analisis bauran pemasaran berisi tentang bagaimana keberhasilan perusahan di bidang pemasaran terkait dalam penentuan sebuah produk yang tepat untuk dipasarkan, penentuan harga yang tepat, saluran distribusi yang nantinya digunakan untuk memasarkan produk, serta promosi yang efektif dalam mengenalkan produk.

Adapun kerangka berfikir dalam metode penelitian yang dilakukan dapat digambarkan pada alur tahap penelitian Gambar 2. Tahapan-tahapan yang dilakukan dimulai dari melakukan identifikasi masalah yang terjadi di Ampu Studio, yaitu adanya permasalahan terhadap pengembangan produk animasi siMbah. Dari identifikasi yang dilakukan kemudian peneliti melakukan pengumpulan data Creativepreneur: Optimalisasi produk animasi "siMbah" dalam komersialisasi ... $\quad$ http://doi.org/10.26594/teknologi.v10i1.2015 Teknologi: Jurnal IImiah Sistem Informasi dengan lisensi CC BY NC SA. 
berupa studi pustaka dari buku dan beberapa referensi penelitian sebelumnya. Pengumpulan data melalui observasi dilakukan di PT. Ampu Kreatif Studio dengan melihat beberapa studio lain sebagai rekanan dan juga kompetitor dalam produk yang sama. Wawancara dan kuesioner dilakukan kepada jajaran manajemen sekaligus karyawan Ampu Studio serta dilakukan secara online kepada viewer dan follower animasi siMbah di platform YouTube dan Instagram. Dari hasil observasi, wawancara dan kuesioner ditemukan harapan serta target dari pemasaran dan perluasan produk animasi siMbah. Kemudian tahapan terakhir dari penelitian kami melakukan analisis dari hasil data yang didapatkan dan dikumpulkan, sehingga dapat memberikan gambaran produk turunan dan pengembangan berupa merchandise dari animasi siMbah, analisis ini kemudian dikembangkan ke arah pemasaran digital melalui bauran pemasaran.

\section{Hasil dan Pembahasan}

Berdasarkan hasil wawancara dengan tim di Ampu Studio, siMbah saat ini baru terdistribusi di channel YouTube dan belum ada bentuk komersialisasi kekayaan intelektual. Oleh karena itu, perlu untuk dilakukan upaya analisis pengembangan produk kreatif turunan dari konten animasi berupa merchandise yang dapat dijual secara offline dan online.

Analisis bauran pemasaran (marketing mix) berisisi tentang bagaimana keberhasilan suatu perusahaan dalam bidang pemasaran terkait dengan produk yang tepat untuk dipasarkan, penentuan harga yang tepat, saluran distribusi yang akan digunakan untuk memasarkan produk, dan promosi untuk mengenalkan produk. Analisis bauran pemasaran yang ditetapkan dalam penelitian ini adalah untuk analisis value produk berupa merchandise dari hasil komersialisasi siMbah dengan menciptakan sebuah produk merchandise yang akan menjadi peluang bisnis ke depannya bagi Ampu Studio, hal ini dapat dikendalikan oleh perusahaan. Analisis bauran pemasaran yang dapat ditetapkan adalah sebagai berikut:

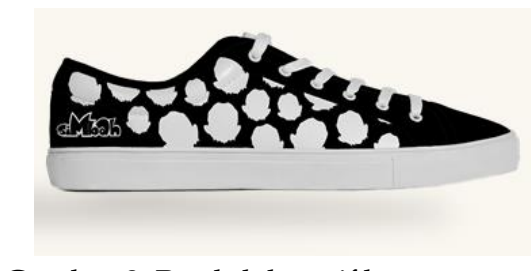

Gambar 3. Produk kreatif berupa sepatu

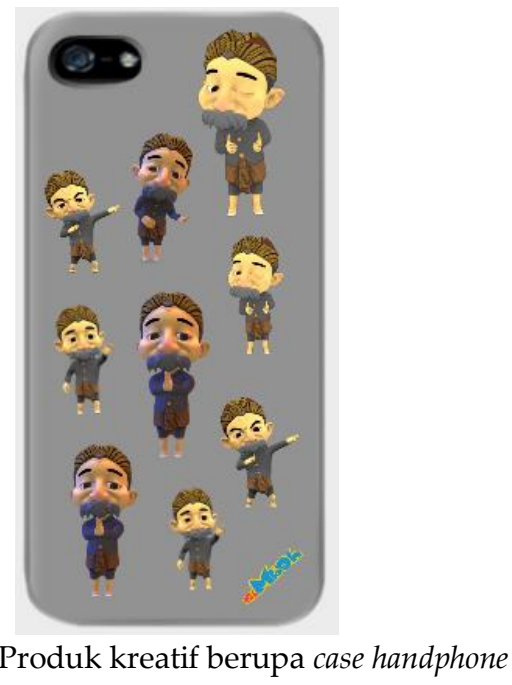

a. Produk

Gambar 4. Produk kreatif berupa case handphone

Produk merupakan kombinasi antara barang dan jasa yang ditawarkan oleh perusahaan kepada konsumen. Sebelum produk diproduksi haruslah dilakukan perencanaan produk apakah yang akan dipasarkan nantinya kepada konsumen. Dalam penentuan produk, perusahaan perlu melihat jenis produk yang akan memberikan manfaat, dapat memenuhi kebutuhan para konsumen, dan tentu saja memberikan kepuasan kepada para konsumen. Sehingga pelanggan atau konsumen sebenarnya akan membeli manfaat dari sesuatu yang ditawarkan, tetapi dengan adanya balutan 
nilai lebih berupa desain dari animasi siMbah. Berikut merupakan kategori produk merchandise untuk siMbah:

Produk hardlines atau garis keras merupakan produk yang terdiri dari barang dagangan yang bersifat keras. Contohnya sepatu pada Gambar 3 dan case handphone (HP) seperti Gambar 4. Produk softlines atau garis lunak merupakan produk yang terdiri dari barang dagangan yang bersifat lunak. Contohnya kaos, pakaian, dan tote-bag, seperti pada Gambar 5.
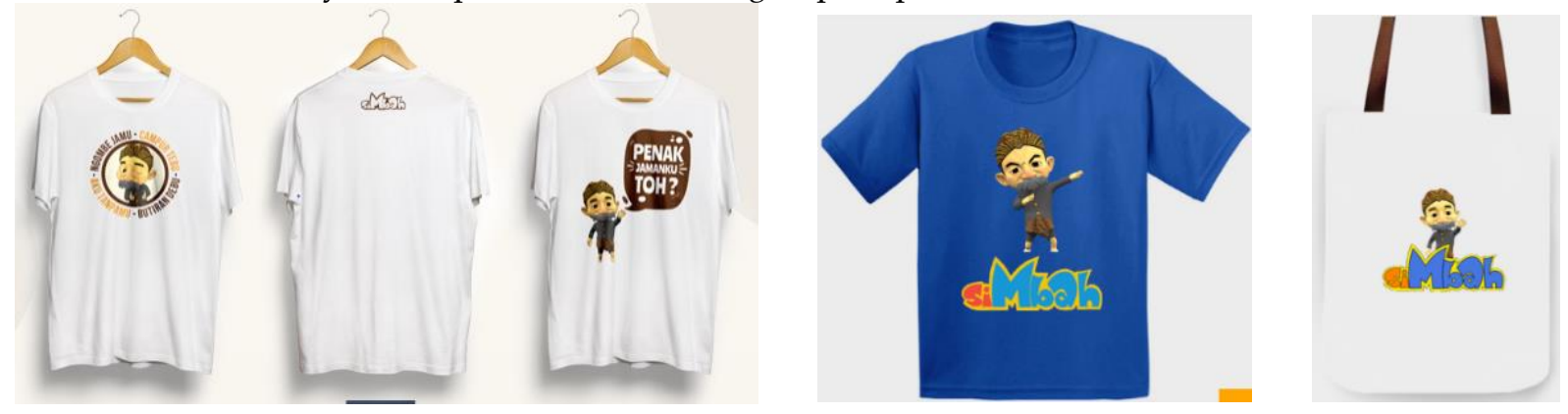

Gambar 5. Produk kreatif berupa kaos, pakaian, dan tote-bag

Produk homelines merupakan produk yang terdiri dari barang prabotan rumah. Contohnya mug, bantal, dan tumbler, seperti pada Gambar 6.
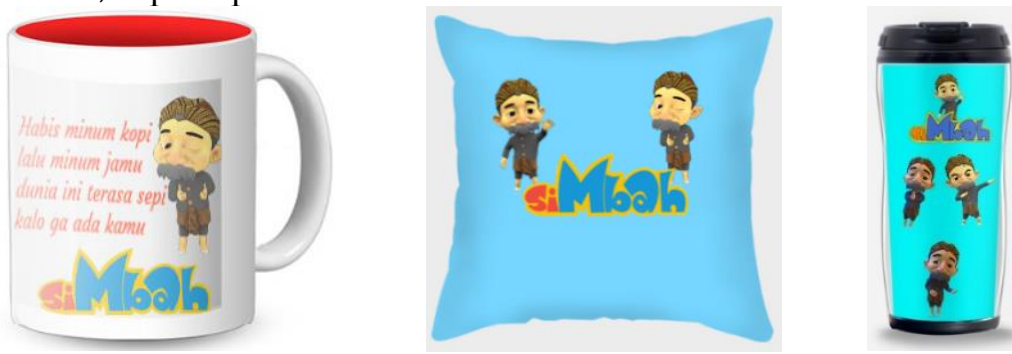

Gambar 6. Produk kretif berupa mug, bantal, dan tumbler

Produk groceries merupakan produk yang terdiri dari produk makanan dan minuman. Misalnya keripik, es krim, seperti pada Gambar 7.
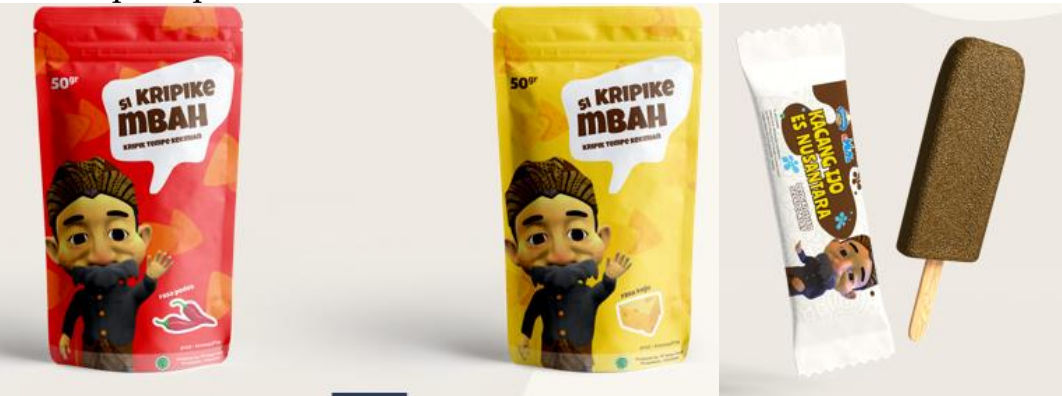

Gambar 7. Produk kretif berupa makanan ringan keripik dan es krim

b. Harga

Penetapan suatu harga produk merupakan bagian dari elemen terpenting bagi sebuah manajemen perusahaan. Penetapan besarnya harga akan mempengaruhi pendapatan total dan biaya dari perusahaan. Harga produk ditetapkan berdasarkan adanya perhitungan besarnya anggaran biaya yang dikeluarkan dalam memproduksi sebuah produk yaitu meliputi biaya bahan baku, harga pokok produksi, biaya untuk promosi dan ditambah dengan besaran persentase keuntungan yang diinginkan. Harga yang ditetapkan setiap produk juga beragam tergantung dari desain produk, jenis bahan, ukuran dan tingkat kerumitan dari produksi produk yang akan dijual. Penempatan harga untuk pengembangan produk kreatif berupa merchandise siMbah ditetapkan berdasarkan kategori dari setiap produk, jenis bahan yang digunakan, dan ukuran dari produk. Misalkan produk kaos, penempatan harga ditetapkan berdasarkan dari jenis kain, ukuran, biaya sablon, dan desain gambar dari siMbah.

Salah satu fungsi dalam bisnis yang utama, yaitu penerimaan order. Penentuan harga dan layanan bisnis kepada pelanggan dapat mempengaruhi terjadinya pembelian dan akan menentukan kepuasan pelanggan (Santoso \& Affandi, 2016).

c. Tempat 
Tempat merupakan saluran distribusi yang digunakan untuk menjual suatu produk dari perusahaan yang memproduksi produk bagi para pelanggan. Tempat yang digunakan untuk memasarkan pengembangan produk kereatif berupa merchandise siMbah adalah lokawisata yang terdapat di Purwokerto Jawa Tengah, karena Purwokerto memiliki banyak sekali tempat-tempat pariwisata. Tujuannya selain mengenalkan siMbah kepada masyarakat dapat juga dijadikan peluang bisnis, karena di Purwokerto masih jarang produsen produk kreatif dari karakter animasi. Dapat juga dipasarkan memalui toko online seperti Bukalapak, Shopee, Tokopedia atau dapat dipesan secara langsung pada produsen. Jangkauan tempat menjadi suatu yang harus dipertimbangkan secara matang, dengan adanya penetrasi internet di semua penjuru Indonesia bahkan internasional, jangkauan tempat dapat lebih diakses dengan mudah melalui platform $e$ commerce dan marketplace secara langsung.

d. Promosi

Promosi merupakan serangkaian kegiatan yang dilakukan dalam upaya memberitahu, mengenalkan, dan mempengaruhi konsumen untuk mengenal produk yang ditawarkan dari suatu perusahaan sehingga berakhir pada ketertarikan dan terjadi pembelian. Promosi yang dilakukan untuk produk kreatif berupa merchandise siMbah yaitu dengan promosi melalui media sosial berupa Instagram, Facebook, web, dimulai dengan awalan yaitu membuat merek yang mengasosiasikan keunggulan dari produk yang ditawarkan.

Media sosial sebagai media jejaring sosial secara maya dapat mempertemukan para pengguna melalui jaringan internet, dengan mudah dapat saling berkomunikasi dan berpartisipasi, berbagi, mengirim pesan, gambar, video hingga emoticon atau sticker. Termasuk di dalamnya, media sosial yaitu web-blog, v-log, social network, wiki, forum dan messenger. Blog, jejaring sosial dan wiki merupakan bagian dari bentuk media sosial yang paling umum untuk dapat digunakan oleh masyarakat di seluruh dunia. Media sosial online merupakan media yang didesain untuk memudahkan masyarakat saling berinteraksi sosial melaui teknologi internet yang mengubah pola penyebaran informasi dari sebelumnya bersifat broadcast media monologue (satu ke banyak audiens) ke media sosial dialogue (banyak audiens ke banyak audiens) berupa group. Jenis serta komposisi media sosial online di internet sangat beragam, antara lain Facebook, Instagram, Linkedln, dan microblogging platform seperti Twitter, termasuk jejaring berbagai foto serta video Flickr dan Youtube, hingga Podcast, chat groups, chat rooms, forum, message board, mailing list, serta masih ada banyak lainnya.

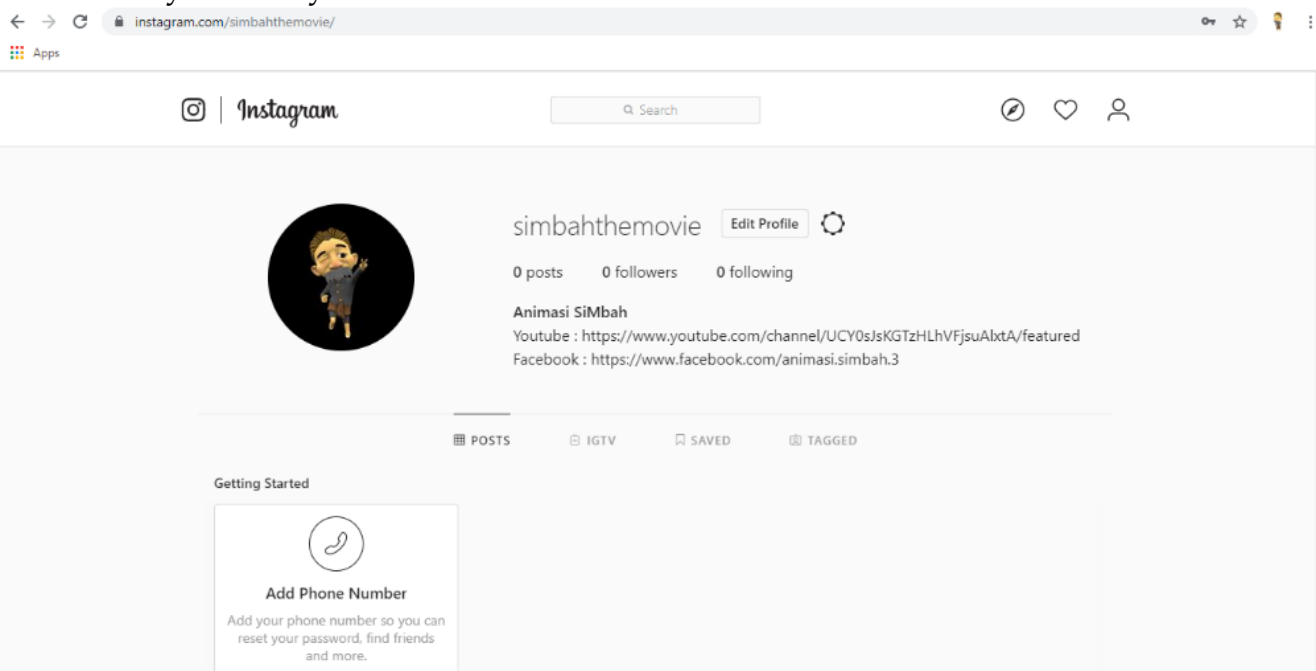

Gambar 8. Akun media sosial Instagram siMbah

Media sosial dapat dialih fungsikan sebagai media untuk mengumpulkan dan menyebarkan informasi. Melalui sosial media dapat mengumpulkan sejumlah informasi dan pengetahuan, namun para pengguna harus bijak dalam menyaring informasi tersebut, dikarenakan banyak informasi palsu atau hoax yang tidak terjamin kebenarannya. Oleh karena itu, melalui sosial media dapat berperan efektif dalam tindakan bersosialisasi hingga mempengaruhi khalayak secara digital, sehingga efek yang dirasakan dapat secara nyata. Banyaknya faktor baik positif maupun negatif pada sosial media dapat menimbulkan pengaruh para penggunanya, menjadikan sosial 
media dapat dijadikan sebuah alternatif dalam mencapai tujuan bisnis dan pemasaran suatu produk.

Pembuatan akun media sosial siMbah dilakukan dengan tujuan untuk mengenalkan siMbah kepada masyarakat luas. Akun media sosial yang akan digunakan, yaitu media sosial Youtube, Instagram dan Facebook. Pada tahap ini dilakukan pembagian kuesioner untuk menentukan nama akun media sosial yang akan digunakan sebagai identitas dari siMbah. Gambar 8 merupakan akun media sosial Instagram siMbah.

Media sosial Facebook juga memiliki tujuan yang sama dengan media sosial Instagram yaitu sebagai media pengenalan animasi. Selain itu juga media sosial Instagram digunakan untuk mempromosikan produk kreatif berupa merchandise dari siMbah yang nantinya akan diproduksi oleh Ampu Studio sebagai peluang bisnis. Untuk media sosial Facebook nama akun berbeda dengan media sosial YouTube dan Instagram, dikarenakan pihak Facebook tidak menyetujui nama akun yang dibuat yaitu siMbah The Movie, oleh karena itu nama akun media sosial Facebook diubah menjadi Animasi siMbah. Gambar 9 merupakan akun media sosial Facebook siMbah.

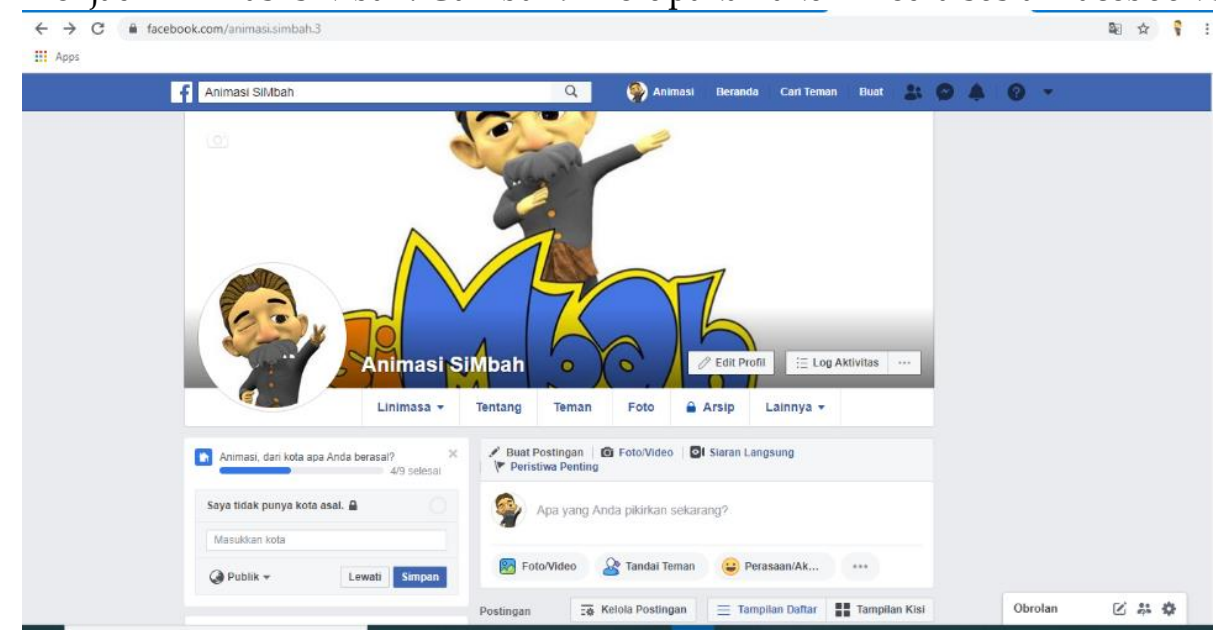

Gambar 9. Akun media sosial Facebook siMbah

Melalui sosial media dapat dilakukan proses digital marketing yang bertujuan untuk kegiatan selama promosi dan pencarian pasar yang tepat melalui media digital secara online. Media sosial merupakan suatu sarana digital marketing yang paling mudah untuk dimanfaatkan. Adanya digital marketing sangat memudahkan para pebisnis dalam melakukan pemantauan dan menyediakan segala kebutuhan, keperluan dan keinginan dari para calon konsumen, di sisi lain calon konsumen dapat dengan mudah dalam mencari dan mendapatkan informasi produk melalui internet atau menjelajah dunia maya, hal ini tentu saja mempermudah dalam proses pencariannya.

Digital marketing juga dapat menjangkau seluruh lapisan masyarakat secara menyeluruh dari ekonomi tingkat atas hingga masyarakat dengan ekonomi tingkat bawah di mana pun mereka berada tanpa adanya batasan geografis ataupun tempat, tentunya selama mereka terkoneksi dengan internet (Purwana, Rahmi, \& Aditya, 2017). Oleh karena itu, digital marketing sangatlah tepat untuk pengenalan video siMbah serta sebagai media promosi untuk pengembangan produk merchandise siMbah.

Banyaknya fitur yang diberikan oleh sosial media tentu memiliki potensi yang besar, hal ini akan memberikan dampak kepada perusahaan seperti meningkatnya Brand Awareness, targeting iklan lebih spesifik mulai dari jenis kelamin, lokasi dan demografi pengguna, ketertarikan, history kunjungan situs, jenis pekerjaan, tingkat pendapatan, adanya kebiasaan, connection, dan lain sebagainya. Adanya penggunaan sosial media yang tepat bagi Ampu Studio akan meningkatkan potensi penjualan dan akan memberikan dampak naiknya traffic pengunjung web perusahaan serta akses komunikasi langsung melalui pesan WhatsApp.

\section{Kesimpulan}

Dari analisis yang telah dilakukan pada Ampu Studio untuk siMbah didapatkan hasil berupa perencanaan strategi untuk produk kreatif berupa produk-produk merchandise berupa produk hardlines, softlines, homelines dan groceries dengan konten siMbah. Hasil strategi digital marketing yaitu melalui 
sosial media berupa Facebook marketing, Instagram, YouTube, marketplace, dan webe toko online untuk pemasaran produk. Saran yang penulis berikan dari hasil penelitian yang dilakukan diantaranya perlu adanya penelitian guna membuat atau membangun web e-commerce untuk produk-produk kreatif merchandise siMbah. Perlu juga dilakukan penelitian untuk dapat mengimplementasikan strategistrategi yang telah diusulkan dalam penelitian ini. Hasil penelitian ini diharapkan dapat digunakan sebagai bahan pertimbangan Ampu Studio untuk mengambil sebuah keputusan, sehingga dapat mencapai tujuan bisnis dengan memproduksi produk kreatif berupa merchandise siMbah yang akan menjadi peluang bisnis kedepannya.

\section{Ucapan Terima Kasih}

Ucapan terima kasih penulis sampaikan kepada tim PT Ampu Kreatif Studio dan Universitas Amikom Purwokerto yang telah membantu dalam penelitian ini.

\section{Referensi}

Bachtiar, M. A., \& Hakim, L. (2016). Game petualangan untuk meningkatkan minat belajar siswa tentang sejarah kemerdekaan Bangsa Indonesia. Teknologi: Jurnal Ilmiah Sistem Informasi, 6(2), 8089.

BPS, B. (2020, Agustus 5). Ekonomi Indonesia 2019 Tumbuh 5,02 Persen. Retrieved from Badan Pusat Statistik: https://www.bps.go.id/pressrelease/2020/02/05/1755/ekonomi-indonesia-2019-tumbuh-502-persen.html

Handani, S. W., \& Nafianti, D. R. (2017). Perancangan Film Pendek Animasi 3 Dimensi Legenda Desa Penyarang. JURNAL INFOTEL, 9(2), 204-2011.

Handani, S. W., Suyanto, M., \& Sofyan, A. F. (2016). Penerapan Konsep Gamifikasi pada E-Learning untuk Pembelajaran Animasi 3 Dimensi. Telematika, 9(1), 42-53.

Hessler, D. (2019). Whose pain is it, anyway? On avatar embodiment, slapstick performances, and virtual pain. Journal Comedy Studies, 11(1), 85-103.

Ilyas, A., Raharja, S., \& Muhandri, T. (2016). Strategi Pemasaran Produk Animasi PT Ayena Mandiri Sinema. Manajemen IKM: Jurnal Manajemen Pengembangan Industri Kecil Menengah, 11(1), 10-19.

Jiao, H., Wang, Y., Xiao, H., Zhou, J., \& Zeng, W. (2017). Promoting Profit Model Innovation in Animation Project in Northeast Asia: Case Study on Chinese Cultural and Creative Industry. Sustainability, 9(12), 2361.

Munir, M. (2013). Multimedia Konsep \& Aplikasi dalam Pendidikan. Bandung: Alfabeta.

Praja, F. K. (2017, Mei 4). Hak Atas Kekayaan Intelektual (HaKI). Retrieved from Dunia Dosen: https://www.duniadosen.com/hak-atas-kekayaan-intelektual-haki/

Purwana, D., Rahmi, R., \& Aditya, S. (2017). Pemanfaatan Digital Marketing bagi Usaha Mikro, Kecil, dan Menengah (UMKM) di Kelurahan Malaka Sari, Duren Sawit. Jurnal Pemberdayaan Masyarakat Madani, 1(1).

Rahmadianto, S. A., Prasetya, B. P., \& Andito, T. (2019). Peningkatan Pemasaran Melalui Strategi Branding dan Identitas untuk Mocca Animation Studio Malang. Abdimas: Jurnal Pengabdian Masyarakat Universitas Merdeka Malang, 4(1), 17-23.

Santoso, J. B., \& Affandi, A. (2016). Model Arsitektur Enterprise Institusi Pengujian dan Kalibrasi Alat Kesehatan. Teknologi: Jurnal Ilmiah Sistem Informasi, 6(1), 1-7.

Saputra, D. I., Indartono, K., \& Handani, S. W. (2019). Business Models based Technology for Startup. Journal of Innovation in Business and Economics, 3(2), 91-98.

Saputra, D. I., Indartono, K., Handani, S. W., \& Hermawan, H. (2020). Program Pengembangan Kewirausahaan Industri Kreatif di Stmik Amikom Purwokerto. JPPM (Jurnal Pengabdian dan Pemberdayaan Masyarakat), 4(1).

Sefudin, A. (2014). Redefinisi Bauran Pemasaran (Marketing Mix) " $4 \mathrm{P}$ " ke " $4 \mathrm{C}$ " (Studi Kasus pada Universitas Indraprasta PGRI). Journal of Applied Business and Economics, 1(1), 17-23.

Silitonga, D. (2018, Juli 11). Creativepreneur: Bisnis Berbasis Kreativitas. Retrieved from Moselo: https://journal.moselo.com/creativepreneur-bisnis-berbasis-kreativitas-78e17b3de6b3

Sofiandy, D. A., \& Mustikasari, A. (2018). Analisis Segmenting, Targeting, dan Positioning Film Animasi Super Neli Bandung Tahun 2018. e-Proceedings of Applied Science. 4, pp. 274-280. Bandung: Universitas Telkom. 
Vijayakrishnan, V., Harikrishnan, D., \& Babu, D. (2018). Marketing Strategy in Advertisements Using Animated Characters. International Journal of Pure and Applied Mathematics, 119(12), 2841-2852. 